\title{
Paenibacillus prosopidis sp. nov., isolated from the nodules of Prosopis farcta
}

\author{
Angel Valverde, ${ }^{1}$ Amira Fterich, ${ }^{2}$ Mosbah Mahdhi, ${ }^{2}$ Martha- \\ Helena Ramírez-Bahena, ${ }^{3 \dagger}$ Miguel A. Caviedes, ${ }^{4}$ Mohamed Mars, ${ }^{2}$ \\ Encarna Velázquez ${ }^{3}$ and Ignacio D. Rodriguez-Llorente ${ }^{4}$ \\ ${ }^{1}$ Instituto de Recursos Naturales y Agrobiología de Salamanca, Consejo Superior de \\ Investigaciones Científicas (IRNASA-CSIC), Salamanca, Spain \\ 'Laboratoire de Biotechnologies Végétales Appliquées a l'Amélioration des cultures, Faculté des \\ Sciences de Gabes, Gabes, Tunisia \\ ${ }^{3}$ Departamento de Microbiología y Genética, Universidad de Salamanca, Salamanca, Spain \\ ${ }^{4}$ Departamento de Microbiología y Parasitología, Facultad de Farmacia, Sevilla, Spain
}

Correspondence

Encarna Velázquez evp@usal.es
Prosopis farcta is a legume species widely distributed in North Africa and the Middle East. It is the only species of the genus Prosopis that is native to Tunisia and grows naturally in two distinct areas, in the north-east and the south-east, respectively (Pottier-Alapetite, 1979). It is known that this species mainly prefers arid conditions, is well adapted to drought and high temperatures, and exhibits a high degree of salt-tolerance (Dafni \& Negbi, 1978). Legumes are

tPresent address: Laboratoire de Ecologie Microbienne, Universite Claude Bernard, Lyon, France

The GenBank/EMBL/DDBJ accession number for the 16S rRNA gene sequence of $P$. prosopidis PW21 ${ }^{\top}$ is FJ820995.

Electron micrographs of strain $\mathrm{PW} 21^{\top}$, a neighbour-joining tree based on nearly complete $16 \mathrm{~S}$ rRNA gene sequences and a two-dimensional thin-layer chromatogram of polar lipids of strain $\mathrm{PW} 21^{\top}$ are available with the online version of this paper. nodulated by several species of rhizobia, and nodules of species of the genus Prosopis in Africa are produced by Mesorhizobium plurifarium (de Lajudie et al., 1998), Rhizobium etli (Odee et al., 2002) Sinorhizobium saheli (de Lajudie et al., 1994), Sinorhizobium kostiense and Sinorhizobium arboris (Nick et al., 1999). However, it is known that other bacteria may be found in legume root nodules (Trujillo et al., 2006a, b; García-Fraile et al., 2008). In the present study, we describe a novel non-nodulating strain belonging to the genus Paenibacillus, $\mathrm{PW} 21^{\mathrm{T}}$, isolated from root nodules of Prosopis farcta growing in Tunisia. Based on genotypic and phenotypic characterization, strain $\mathrm{PW} 21^{\mathrm{T}}$ should be classified as a novel species of the genus Paenibacillus, for which we propose the name Paenibacillus prosopidis sp. nov.

Root nodules used for isolation of strain $\mathrm{PW} 21^{\mathrm{T}}$ were washed several times with sterile distilled water and were 
then surface sterilized in ethanol $(95 \%, v / v)$ for $15 \mathrm{~s}$ and then in $\mathrm{HgCl}_{2}(2.5 \%$, w/v) for 2 min. Nodules were rinsed five times with sterile distilled water and then crushed using a sterile glass rod. Homogenized nodule tissue was inoculated on modified yeast extract mannitol agar (YMA; Vincent, 1970; $10 \mathrm{~g}$ mannitol $\mathrm{l}^{-1}, 1 \mathrm{~g}$ yeast extract $\mathrm{l}^{-1}$, $0.2 \mathrm{~g} \mathrm{~K}_{2} \mathrm{HPO}_{4} \mathrm{l}^{-1}, 0.2 \mathrm{~g} \mathrm{MgSO}_{4} .7 \mathrm{H}_{2} \mathrm{O} \mathrm{l}^{-1}, 0.5 \mathrm{~g} \mathrm{NaCl} \mathrm{l}^{-1}$, $20 \mathrm{~g}_{\text {agar }} \mathrm{l}^{-1}$ ) and the plates were incubated at $28{ }^{\circ} \mathrm{C}$ for 4 days. Cultures used in further phenotypic and molecular studies were purified from a single colony after 2 days of incubation at $28{ }^{\circ} \mathrm{C}$ on YMA. After isolation, the strain was grown in TY medium ( $3 \mathrm{~g}$ yeast extract $\mathrm{l}^{-1}, 4 \mathrm{~g}$ tryptone

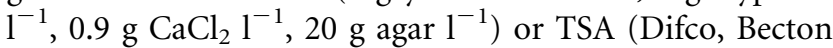
Dickinson, BBL). On TSA medium, colonies of strain PW $21^{\mathrm{T}}$ were white-cream, round, smooth and convex with approximate diameters of $1-3 \mathrm{~mm}$.

Strain PW21 ${ }^{\mathrm{T}}$ was grown in TY agar for $48 \mathrm{~h}$ at $22{ }^{\circ} \mathrm{C}$ to check for motility by phase-contrast microscopy using the hanging drop method. Gram staining was carried out by the procedure described by Doetsch (1981) after $24 \mathrm{~h}$ of incubation at $28{ }^{\circ} \mathrm{C}$. The flagellation type was determined by electron microscopy after $48 \mathrm{~h}$ of incubation in TSA at $22{ }^{\circ} \mathrm{C}$ as previously described by Rivas et al. (2005). For scanning electron microscopy, cells were fixed overnight in phosphate buffer ( $\mathrm{pH} 7.0)$ containing $2 \%$ paraformaldehyde and $0.2 \%$ glutaraldehyde, dehydrated through a graded ethanol series, critical-point dried and sputtercoated with gold. Samples were observed under a Zeiss DSM 490 electron microscope. Strain PW $21^{\mathrm{T}}$ was Gramvariable and motile by means of a polar flagellum [Supplementary Fig. S1(a), available in IJSEM Online]. Round, terminal spores were formed in slightly or nonswollen sporangia [Supplementary Fig. S1(b)].

The 16S rRNA gene of strain PW21 ${ }^{\mathrm{T}}$ was analysed as described by Rivas et al. (2007). The sequence obtained was compared with those from the GenBank database using the BLASTN (Altschul et al., 1990) and EzTaxon (Chun et al., 2007) programs. Sequences were aligned using CLUSTAL $X$ software (Thompson et al., 1997). Distances were calculated according to Kimura's two-parameter method (Kimura, 1980). A phylogenetic tree was inferred by using the neighbour-joining (Saitou \& Nei, 1987) and maximumparsimony (Felsenstein, 1983) methods. Bootstrap analysis was based on 1000 resamplings. The MEGA4.0 package (Tamura et al., 2007) was used for all analyses. The resulting neighbour-joining tree corresponding to $16 \mathrm{~S}$ rRNA gene sequences is shown in Fig. 1 (an extended tree is available as Supplementary Fig. S2). Similar results were obtained by using the maximum-parsimony method (data not shown). The results of the phylogenetic analyses indicated that strain PW $21^{\mathrm{T}}$ is related to members of the genus Paenibacillus. Strain PW $21^{\mathrm{T}}$ formed a cluster together with Paenibacillus

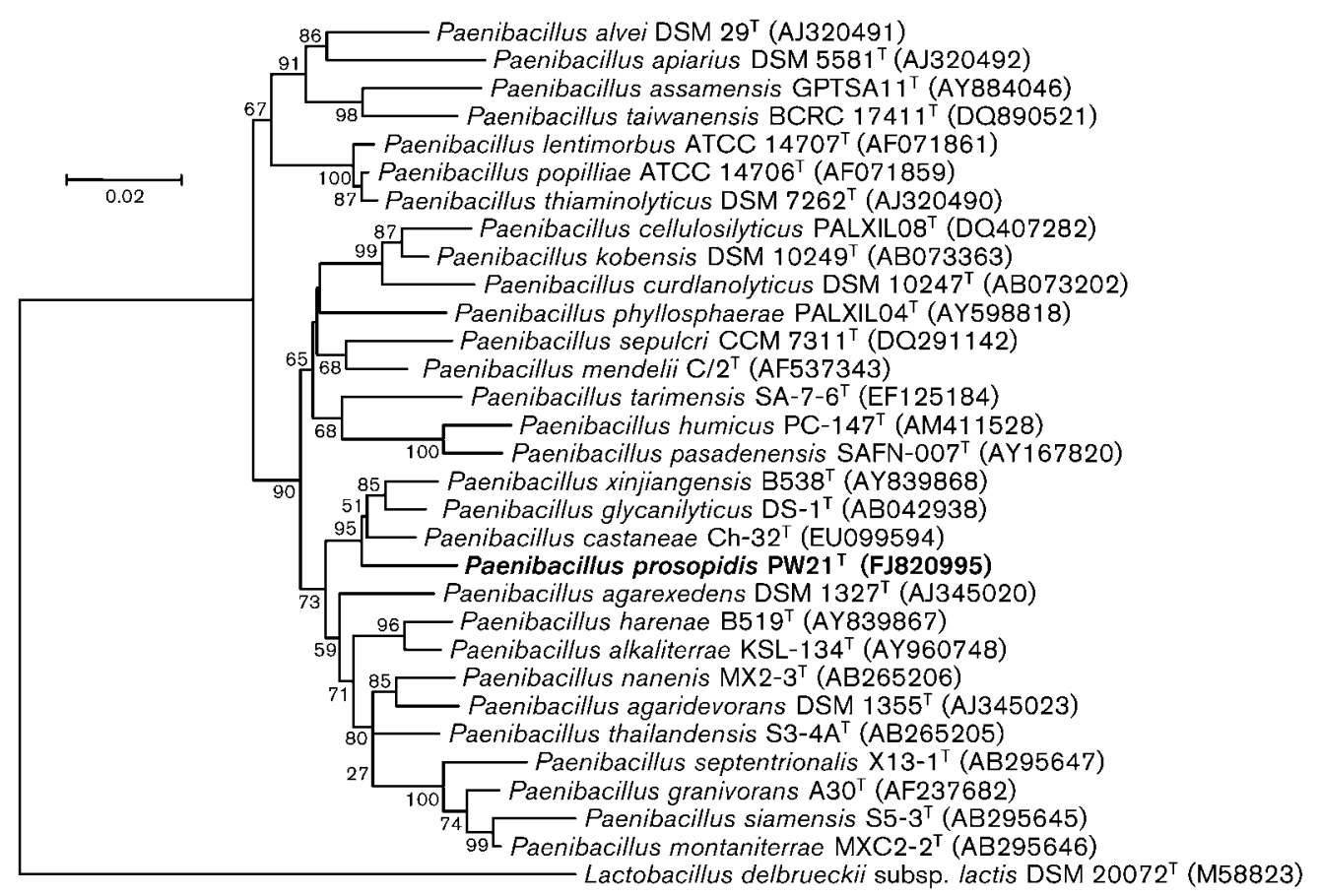

Fig. 1. Neighbour-joining tree based on nearly complete $16 \mathrm{~S}$ rRNA gene sequences showing the relatedness among strain PW $21^{\top}$ and representative species of the genus Paenibacillus. Lactobacillus delbrueckii subsp. lactis DSM $20072^{\top}$ was used as an outgroup. The significance of each branch is indicated by a bootstrap value calculated for 1000 subsets. Bar, $2 \mathrm{nt}$ substitutions per $100 \mathrm{nt}$. 
castaneae Ch- $32^{\mathrm{T}}$, Paenibacillus glycanilyticus DS- $1^{\mathrm{T}}$ and Paenibacillus xinjiangensis $\mathrm{B} 538^{\mathrm{T}}$ with $96.9,96.9$ and $96.4 \%$ sequence identities, respectively.

For base composition analysis, DNA was prepared according to Chun \& Goodfellow (1995). The mol\% $\mathrm{G}+\mathrm{C}$ content of DNA was determined by using the thermal denaturation method (Mandel \& Marmur, 1968). The DNA G + C content of strain PW $21^{\mathrm{T}}$ was $52.9 \mathrm{~mol} \%$. DNA-DNA hybridization was performed by using the method of Ezaki et al. (1989), following the recommendations of Willems et al. (2001). DNA-DNA relatedness values between strain $\mathrm{PW} 21^{\mathrm{T}}$ and $P$. castaneae $\mathrm{Ch}-32^{\mathrm{T}}, P$. glycanilyticus DS- $1^{\mathrm{T}}$ and $P$. xinjiangensis $\mathrm{B} 538^{\mathrm{T}}$ were lower than $25 \%$, confirming that the new isolate represents a novel species of the genus Paenibacillus according to the current species concept (Wayne et al., 1987).

Chemotaxonomic analyses were carried out by the Identification Service and Dr B. J. Tindall, DSMZ, Braunschweig, Germany. The respiratory quinones and polar lipids were analysed as described by Tindall (1990) and the cellular fatty acids according to the instructions of the Microbial Identification System (MIDI; Microbial ID). For analysis of the peptidoglycan, whole cells of strain PW$21^{\mathrm{T}}$ were hydrolysed with $\mathrm{HCl}$ at $100{ }^{\circ} \mathrm{C}$ for $15 \mathrm{~h}$. The hydrolysates were subjected to thin-layer chromatography on cellulose plates using the solvent system of Rhuland et al. (1955). Menaquinone 7 (MK-7) was the major respiratory quinone in strain $\mathrm{PW} 21^{\mathrm{T}}$ and the presence of mesodiaminopimelic acid was not detected in its peptidoglycan. The fatty acid profile of strain PW $21^{\mathrm{T}}$ consisted of anteiso$\mathrm{C}_{15: 0}(48.98 \%)$, iso- $\mathrm{C}_{16: 0}(15.30 \%)$, iso- $\mathrm{C}_{15: 0}(10.09 \%)$, $\mathrm{C}_{16: 0}(4.75 \%)$, anteiso- $\mathrm{C}_{17: 0}(4.59 \%)$, iso- $\mathrm{C}_{17: 0}(5.68 \%)$, iso- $\mathrm{C}_{14: 0}(2.39 \%), \mathrm{C}_{15: 0}(1.96 \%), \mathrm{C}_{16: 1} \omega 11 \mathrm{c}(1.78 \%)$, $\mathrm{C}_{16: 1} \omega 7 c$ alcohol $(1.71 \%)$, iso- $\mathrm{C}_{17: 1} \omega 10 c(1.05 \%)$ and other compounds in proportions lower than $1 \%$. The fatty acid profile of strain PW $21^{\mathrm{T}}$ differs with respect to those of P. glycanilyticus DS $-1^{\mathrm{T}}$ and $P$. castaneae $\mathrm{Ch}-32^{\mathrm{T}}$ in the proportions of iso- $C_{17: 0}$, iso- $C_{16: 0}$, iso- $C_{15: 0}$ and $C_{16: 0}$ and with respect to that of $P$. xinjiangensis DSM $16970^{\mathrm{T}}$ mainly in the proportions of $\mathrm{C}_{16: 0}$ and iso- $\mathrm{C}_{16: 0}$ (Supplementary Table S1, available in IJSEM online). The lipid profile of strain PW $21^{\mathrm{T}}$ (Supplementary Fig. S3) consisted of diphosphatidylglycerol, phosphatidylglycerol, phosphatidylethanolamine, a glycolipid, six phospholipids, an unidentified lipid, and two unknown aminophosphoglycolipids. This profile was very different to that reported for Paenibacillus polymyxa by Kämpfer et al. (2006); nevertheless, as polar lipids have not been analysed in most species of the genus Paenibacillus, at this time they are mainly useful for differentiation from adjacent genera such as Cohnella (Kämpfer et al., 2006), Saccharibacillus (Rivas et al., 2008) and Fontibacillus (Saha et al., 2010).

Phenotypic characterization was performed according to the standard methods described by Claus \& Berkeley (1986) and Logan \& Berkeley (1984) and by using the API 20NE, API20E and API50CH systems (bioMérieux) according to the manufacturer's instructions. Anaerobic growth was tested in fluid tetrathionate medium (Sigma). Acetoin production, ability to grow in the presence of 2,5 and $7 \% \mathrm{NaCl}$, nitrate reduction, and phenylalanine deaminase, catalase, gelatinase, caseinase and oxidase activities were analysed as described by Claus \& Berkeley (1986). Acid production from glucose, xylose, mannitol and L-arabinose and gas production from glucose were analysed in liquid medium as described by Claus \& Berkeley (1986). Amylases, xylanases and cellulases were analysed as described earlier using TSA as basal medium supplemented with the polysaccharides at $7 \mathrm{~g} \mathrm{l}^{-1}$ (Rivas et al. 2003). Growth was determined at temperatures ranging from 4 to $45{ }^{\circ} \mathrm{C}$ in TSA medium. Growth at pH 5.7 and 6.8 was tested as described by Claus \& Berkeley (1986); growth at $\mathrm{pH} 7-8$ was tested in TY medium containing $200 \mathrm{mM} \mathrm{Na} 2 \mathrm{HPO}_{4} / \mathrm{NaH}_{2} \mathrm{PO}_{4}$ and growth at $\mathrm{pH} 9$ and 10 was tested in the same medium containing $200 \mathrm{mM} \mathrm{NaHCO} / \mathrm{Na}_{2} \mathrm{CO}_{3}$. The type strains of the most closely related species, $P$. glycanilyticus, $P$. castaneae and $P$. xinjiangensis, were included in the phenotypic study as references. Results are given in the species description below. Strain $\mathrm{PW} 21^{\mathrm{T}}$ could be differentiated from $P$. glycanilyticus by colony colour, ability to grow at $\mathrm{pH} 5.7$ and assimilation of L-rhamnose, glycerol and $\mathrm{N}$-acetylglucosamine as carbon source, from P. castaneae by colony colour, ability to grow at $\mathrm{pH} 5.7$, gelatin and starch hydrolysis and assimilation of L-rhamnose as carbon source, and from $P$. xinjiangensis by ability to hydrolyse starch and to assimilate L-rhamnose, glycerol and mannitol as carbon source (Table 1).

Strain $\mathrm{PW} 21^{\mathrm{T}}$ can be genotypically and phenotypically differentiated from previously described species and therefore represents a novel species, which we propose to name Paenibacillus prosopidis sp. nov.

\section{Description of Paenibacillus prosopidis sp. nov.}

Paenibacillus prosopidis (pro.so'pi.dis. L. n. prosopis name of a plant, and also a botanical genus name; L. gen. n. prosopidis of Prosopis, isolated from Prosopis farcta).

Cells are Gram-variable and motile by means of a polar flagellum. Round, terminal spores are formed in slightly or non-swollen sporangia. Catalase-positive and weakly oxidase-positive. Colonies on nutrient agar medium are whitecream, round, smooth and convex with approximate diameters of $1-3 \mathrm{~mm}$. The major quinone is MK-7 and meso-diaminopimelic acid is not detected in the peptidoglycan. The lipid profile consists of diphosphatidylglycerol, phosphatidylglycerol, phosphatidylethanolamine, a glycolipid, six phospholipids, an unidentified lipid, and two unknown aminophosphoglycolipids. The main fatty acids are anteiso- $\mathrm{C}_{15: 0}$, iso- $\mathrm{C}_{16: 0}$ and iso- $\mathrm{C}_{15: 0}$. Anaerobic growth is negative. Does not grow at $\mathrm{pH} 5.7$ or at $\mathrm{pH} 9$. Grows between pH 6.5 and 8 (optimal pH 7). Grows in the presence of $2 \% \mathrm{NaCl}$ but not $5 \% \mathrm{NaCl}$. Grows at $37{ }^{\circ} \mathrm{C}$ but not at $4{ }^{\circ} \mathrm{C}$. Growth at $40{ }^{\circ} \mathrm{C}$ is weak. Optimal temperature 
Table 1. Differential phenotypic characteristics of strain $P W 21^{\top}$ and phylogenetically related species of the genus Paenibacillus

Strains: 1, Paenibacillus prosopidis sp. nov. PW21 ${ }^{\mathrm{T}}$ (data from this study); 2, Paenibacillus glycanilyticus DS- $1^{\mathrm{T}}$ (Dasman et al., 2002; Yoon et al., 2005); 3, Paenibacillus castaneae Ch- $32^{\mathrm{T}}$ (Valverde et al., 2008); 4, Paenibacillus xinjiangensis $\mathrm{B} 538^{\mathrm{T}}$ (Lim et al., 2006). +, Positive reaction; -, negative reaction; $\mathrm{w}$, weakly positive reaction; $\mathrm{v}$, variable.

\begin{tabular}{|c|c|c|c|c|}
\hline Characteristics & 1 & 2 & 3 & 4 \\
\hline Gram stain & V & + & V & + \\
\hline Colony colour & White-cream & Pinkish yellow & Yellow & White-cream \\
\hline \multicolumn{5}{|l|}{ Growth at: } \\
\hline pH 5.7 & - & + & + & - \\
\hline $40{ }^{\circ} \mathrm{C}$ & $\mathrm{W}$ & + & - & $-\dagger$ \\
\hline \multicolumn{5}{|l|}{ Hydrolysis of: } \\
\hline Gelatin & - & - & + & $-\dagger$ \\
\hline Starch & + & + & 一キ & - \\
\hline \multicolumn{5}{|l|}{ Assimilation of: } \\
\hline D-Mannose & $\mathrm{W}$ & + & + & + \\
\hline L-Rhamnose & - & + & + & + \\
\hline
\end{tabular}

${ }^{\star}$ Oxidase reported as negative by Yoon et al. (2005).

$\dagger$ Data from this study.

$\$$ Negative in flooding with Lugol’s iodine solution.

for growth is $30{ }^{\circ} \mathrm{C}$. Nitrate is not reduced to nitrite. Produces $\beta$-galactosidase but does not produce indole, phenylalanine deaminase, urease, arginine dehydrolase, ornithine or lysine decarboxylase. Acetoin production is weak. Hydrolyses aesculin but not gelatin in API20NE and API20E, respectively. Hydrolyses cellulose, starch and xylan but not casein. In the API 20NE system, assimilation of glucose, L-arabinose, mannitol, maltose, gluconate and malate is positive and that of $N$-acetylglucosamine, caprate, citrate, adipate, L-malate and phenylacetate is negative. Assimilation of mannose is weakly positive. Acid, but not gas, is produced from glucose. In API $50 \mathrm{CH}$, acid production from L-arabinose, D-ribose, D-xylose, methyl $\alpha$ D-xyloside, galactose, glucose, dulcitol, sorbitol, salicin, cellobiose, maltose, lactose, melibiose, sucrose, trehalose, raffinose and amygdalin is positive. Acid production from glycerol, erythritol, D-arabinose, L-xylose, adonitol, Lsorbose, L-rhamnose, inositol, mannitol, sorbitol, methyl $\alpha$-D-mannoside, methyl $\alpha$-D-glucoside, $N$-acetylglucosamine, amygdalin, inulin, melezitose, xylitol, gentiobiose, turanose, L-lyxose, tagatose, D-fucose, L-fucose, D-arabinitol and $\mathrm{L}$-arabinitol is negative. Acid production from mannose, fructose and glycogen is weakly positive. Hydrolysis of arbutin and aesculin is positive. The DNA G $+\mathrm{C}$ content of the type strain is $52.9 \mathrm{~mol} \%$.

The type strain, PW $21^{\mathrm{T}}\left(=\mathrm{LMG} 25259^{\mathrm{T}}=\mathrm{CECT} 7506^{\mathrm{T}}\right.$ $=$ DSM $22405^{\mathrm{T}}$ ), was isolated from the nodules of Prosopis farcta in Tunisia.

\section{Acknowledgements}

This work was supported by the AECID (project A/018017/08) and JCYL (GR49). A. F. was supported by a fellowship from the University of Gabés. A.V. was supported by a postdoctoral JAE-Doc (CSIC) contract. We thank Dr J. P. Euzéby for etymological advice and the Identification Service and Dr B. Tindall, DSMZ, for the chemotaxonomic analyses.

\section{References}

Altschul, S. F., Gish, W., Miller, W., Myers, E. W. \& Lipman, D. J. (1990). Basic local alignment search tool. J Mol Biol 215, 403-410.

Chun, J. \& Goodfellow, M. (1995). A phylogenetic analysis of the genus Nocardia with $16 \mathrm{~S}$ rRNA sequences. Int J Syst Bacteriol 45, 240 245.

Chun, J., Lee, J.-H., Jung, Y., Kim, M., Kim, S., Kim, B. K. \& Lim, Y.-W. (2007). EzTaxon: a web-based tool for the identification of prokaryotes based on $16 \mathrm{~S}$ ribosomal RNA gene sequences. Int J Syst Evol Microbiol 57, 2259-2261.

Claus, D. \& Berkeley, R. C. W. (1986). Genus Bacillus Cohn 1872, $174^{\mathrm{AL}}$. In Bergey's Manual of Systematic Bacteriology, vol. 2, pp. 11051139. Edited by P. H. A. Sneath, N. S. Mair, M. E. Sharpe \& J. G. Holt. Baltimore: Williams \& Wilkins.

Dafni, A. \& Negbi, M. (1978). Variability in Prosopis farcta in Israel: seed germination as affected by temperature and salinity. Isr J Bot 27, 147-159.

Dasman, Kajiyama, S., Kawasaki, H., Yagi, M., Seki, T., Fukusaki, E. \& Kobayashi, A. (2002). Paenibacillus glycanilyticus sp. nov., a novel species that degrades heteropolysaccharide produced by the 
cyanobacterium Nostoc commune. Int J Syst Evol Microbiol 52, 16691674.

de Lajudie, P., Willems, A., Pot, B., Dewettinck, D., Maestrojuan, G., Neyra, M., Collins, M. D., Dreyfus, B., Kersters, K. \& Gillis, M. (1994). Polyphasic taxonomy of rhizobia: emendation of the genus Sinorhizobium and description of Sinorhizobium meliloti comb. nov., Sinorhizobium saheli sp. nov. and Sinorhizobium teranga sp. nov. Int J Syst Bacteriol 48, 715-733.

de Lajudie, P., Willems, A., Nick, G., Moreira, F., Molouba, F., Hoste, B. Torck, U., Neyra, M., Collins, M. D. \& other authors (1998). Characterization of tropical tree rhizobia and description of Mesorhizobium plurifarium sp. nov. Int J Syst Bacteriol 48, 369-382.

Doetsch, R. N. (1981). Determinative methods of light microscopy. In Manual of Methods for General Bacteriology, pp. 21-33. Edited by P. Gerdhardt, R. G. E. Murray, R. N. Costilow, E. W. Nester, W. A. Wood, N. R. Krieg \& G. B. Phillips. Washington, DC: American Society for Microbiology.

Ezaki, T., Hashimoto, Y. \& Yabuuchi, E. (1989). Fluorometric deoxyribonucleic acid-deoxyribonucleic acid hybridization in microdilution wells as an alternative to membrane filter hybridization in which radioisotopes are used to determine genetic relatedness among bacterial strains. Int J Syst Bacteriol 39, 224-229.

Felsenstein, J. (1983). Parsimony in systematics: biological and statistical issues. Annu Rev Ecol Syst 14, 313-333.

García-Fraile, P., Velázquez, E., Mateos, P. F., Martínez-Molina, E. \& Rivas, R. (2008). Cohnella phaseoli sp. nov., isolated from root nodules of Phaseolus coccineus in Spain, and emended description of the genus Cohnella. Int J Syst Evol Microbiol 58, 1855-1859.

Kämpfer, P., Rosselló-Mora, R., Falsen, E., Busse, H.-J. \& Tindall, B. J. (2006). Cohnella thermotolerans gen. nov., sp. nov., and classification of 'Paenibacillus hongkongensis' as Cohnella hongkongensis sp. nov. Int J Syst Evol Microbiol 56, 781-786.

Kimura, M. (1980). A simple method for estimating evolutionary rates of base substitutions through comparative studies of nucleotide sequences. J Mol Evol 16, 111-120.

Lim, J.-M., Jeon, C. O., Park, D.-J., Xu, L.-H., Jiang, C.-L. \& Kim, C.-J. (2006). Paenibacillus xinjiangensis sp. nov., isolated from Xinjiang province in China. Int J Syst Evol Microbiol 56, 2579-2582.

Logan, N. A. \& Berkeley, R. C. W. (1984). Identification of Bacillus strains using the API system. J Gen Microbiol 130, 1871-1882.

Mandel, M. \& Marmur, J. (1968). Use of ultraviolet absorbancetemperature profile for determining the guanine plus cytosine content of DNA. Methods Enzymol 12B, 195-206.

Nick, G., de Lajudie, P., Eardly, B. D., Suomalainen, S., Paulin, L., Zhang, X., Gillis, M. \& Lindström, K. (1999). Sinorhizobium arboris sp. nov. and Sinorhizobium kostiense sp. nov., isolated from leguminous trees in Sudan and Kenya. Int J Syst Bacteriol 49, 1359-1368.

Odee, D. W., Haukka, K., McInroy, S. G., Sprent, J. I., Sutherland, J. M. \& Young, J. P. W. (2002). Genetic and symbiotic characterization of rhizobia isolated from tree and herbaceous legumes grown in soils from ecologically diverse sites in Kenya. Soil Biol Biochem 34, 801-811.

Pottier-Alapetite, G. (1979). Flore de la Tunisie: AngiospermesDicotylédones, Apétales Dialypétales, vol. 1. Tunis: Publications Scientifiques Tunisiennes. Ministère de l'Enseignement Supérieur et de la Recherche Scientifique et le Ministère de l'Agriculture.

Rhuland, L. E., Work, E., Denman, R. F. \& Hoare, D. S. (1955). The behavior of the isomers of $\alpha, \varepsilon$-diaminopimelic acid on paper chromatograms. J Am Chem Soc 77, 4844-4846.
Rivas, R., Sánchez, M., Trujillo, M. E., Zurdo-Piñeiro, J. L., Mateos, P. F., Martínez-Molina, E. \& Velázquez, E. (2003). Xylanimonas cellulosilytica gen. nov., sp. nov., a xylanolytic bacterium isolated from a decayed tree (Ulmus nigra). Int J Syst Evol Microbiol 53, 99103.

Rivas, R., Gutiérrez, C., Abril, A., Mateos, P. F., Martinez-Molina, E., Ventosa, A. \& Velázquez, E. (2005). Paenibacillus rhizosphaerae sp. nov., isolated from the rhizosphere of Cicer arietinum. Int J Syst Evol Microbiol 55, 1305-1309.

Rivas, R., García-Fraile, P., Mateos, P. F., Martínez-Molina, E. \& Velázquez, E. (2007). Characterization of xylanolytic bacteria present in the bract phyllosphere of the date palm Phoenix dactylifera. Lett Appl Microbiol 44, 181-187.

Rivas, R., García-Fraile, P., Zurdo-Piñeiro, J. L., Mateos, P. F., Martínez-Molina, E., Bedmar, E. J., Sánchez-Raya, J. \& Velázquez, E. (2008). Saccharibacillus sacchari gen. nov., sp. nov., isolated from sugar cane. Int J Syst Evol Microbiol 58, 1850-1854.

Saha, P., Krishnamurthi, S., Bhattacharya, A., Sharma, R. \& Chakrabarti, T. (2010). Fontibacillus aquaticus gen. nov., sp. nov., isolated from a warm spring. Int J Syst Evol Microbiol 60, 422-428.

Saitou, N. \& Nei, M. (1987). The neighbour-joining method: a new method for reconstructing phylogenetic trees. Mol Biol Evol 4, 406425.

Tamura, K., Dudley, J., Nei, M. \& Kumar, S. (2007). MEGA4: molecular evolutionary genetics analysis (MEGA) software version 4.0. Mol Biol Evol 24, 1596-1599.

Thompson, J. D., Gibson, T. J., Plewniak, F., Jeanmougin, F. \& Higgins, D. G. (1997). The CLUSTAL_X windows interface: flexible strategies for multiple sequence alignment aided by quality analysis tools. Nucleic Acids Res 25, 4876-4882.

Tindall, B. J. (1990). Lipid composition of Halobacterium lacusprofundi. FEMS Microbiol Lett 66, 199-202.

Trujillo, M. E., Kroppenstedt, R. M., Schumann, P., Carro, L. \& Martínez-Molina, E. (2006a). Micromonospora coriariae sp. nov., isolated from root nodules of Coriaria myrtifolia. Int J Syst Evol Microbiol 56, 2381-2385.

Trujillo, M. E., Kroppenstedt, R. M., Schumann, P. \& MartínezMolina, E. (2006b). Kribbella lupini sp. nov., isolated from the roots of Lupinus angustifolius. Int J Syst Evol Microbiol 56, 407-411.

Valverde, A., Peix, A., Rivas, R., Velázquez, E., Salazar, S., SantaRegina, I., Rodríguez-Barrueco, C. \& Igual, J. M. (2008). Paenibacillus castaneae sp. nov., isolated from the phyllosphere of Castanea sativa Miller. Int J Syst Evol Microbiol 58, 2560-2564.

Vincent, J. M. (1970). The cultivation, isolation and maintenance of rhizobia. In A Manual for the Practical Study of Root-Nodule Bacteria, pp. 1-13. Edited by J. M. Vincent. Oxford: Blackwell Scientific.

Wayne, L. G., Brenner, D. J., Colwell, R. R., Grimont, P. A. D., Kandler, O., Krichevsky, M. I., Moore, L. H., Moore, W. E. C., Murray, R. G. E. \& other authors (1987). Report of the ad hoc committee on reconciliation of approaches to bacterial systematics. Int J Syst Bacteriol 37, 463-464.

Willems, A., Doignon-Bourcier, F., Goris, J., Coopman, R., de Lajudie, P., De Vos, P. \& Gillis, M. (2001). DNA-DNA hybridization study of Bradyrhizobium strains. Int $J$ Syst Evol Microbiol 51, 1315-1322.

Yoon, J.-H., Kang, S.-J., Yeo, S.-H. \& Oh, T.-K. (2005). Paenibacillus alkaliterrae sp. nov., isolated from an alkaline soil in Korea. Int J Syst Evol Microbiol 55, 2339-2344. 